DOI: 10.17117/na.2016.11.02.350

Поступила (Received): 24.11.2016

\title{
Воробьева О.В.
}

\author{
Анализ иммуногистохимической реакции на белок Кі 67 \\ в костном мозге и аппендиксе при аутогенной костного \\ м03га
}

\author{
Vorobyova O.V. \\ Analysis immunohistochemical reactions Ki 67 protein in the \\ bone marrow during the appendix and autologous bone \\ marrow transplantation
}

У опытных мышей после аутопересадки в костном мозге и аппендиксе наблюдается усиление пролиферативных процессов, причем выраженность усиленного митотического деления клеток наблюдается преимущественно в аппендиксе. Кроме того, костный мозг и аппендикс после аутопересадки функционируют сопряженно, т.е. по данным корреляционного анализа выявляется в этих двух органах синтез нейроаминов и их выделение происходит одновременно

Ключевые слова: трансплантация костного мозга, тучные клетки

\section{Воробьева Ольга Васильевна}

Кандидат медицинских наук, доцент

Чувашский государственный университет им. И.Н.

Ульянова

2. Чебоксары, Московский пр., 15
In the experimental mice after bone marrow autograft in appendix and proliferative processes has been increasing, and the severity of the enhanced mitotic cell division is observed mainly in the appendix. In addition, bone marrow, and the appendix after autograft conjugate function, ie, According to the correlation analysis revealed in these two organs neyroaminov synthesis and release occurs simultaneously

Key words: bone marrow transplantation, mast cells

\section{Vorobyova Olga Vasilevna}

Candidate of Medical Sciences, Associate Professor

Chuvash state university named I.N. Ulyanov

Cheboksary, Moskovsky ave., 15

Пересадка костного мозга в последнее время является актуальным методом оказания специализированной помощи людям с онкологическими, гематологическими заболеваниями, протекающие с поражением кроветворной и иммунной систем [1,2,3]. При этом полного излечения удается достичь только в $60 \%$ случаев, часто развивается реакция «Трансплантант против хозяина». Костный мозг является центральным органом кроветворения, а аппендикс является периферическим органом кроветворения и иммунитета. По данным литературы [1,2] между костным мозгом и аппендиксом существует тесное взаимодействие. Так, предшественники В-лимфоцитов мигрируют из костного мозга в аппендикс, где происходит их размножение и созревание. Можно пред- 
положить, что в некоторых случаях при гибели костного мозга можно часть клеток трансплантировать из своего же органа - аппендикса. В связи с чем, очень важно изучить иммуногистохимическую реакцию в костном мозге и аппендиксе при аутопересадке.

Цель - произвести сравнительный иммуногистохимический анализ на белок Ki 67 костного мозга и аппендикса при аутогенной пересадке костного мозга.

Материал и методы исследования: 1-я группа - интактные мыши без введения; 2-я группа - мышам внутривенно вводили суспензию костного мозга, полученную от этой же мыши. Взятый из бедренной кости 0,1 мл костного мозга помещали в 2 мл физиологического раствора и тщательно размешивали. Суспензию костного мозга вводили в хвостовую вену этой же мыши. Подсчет числа клеток в полученной суспензии костного мозга производили с помощью проточного спектрофотометра «Ф-2000». Проводили иммуногистохимический метод для выявления пролиферации клеток, экспрессирующих маркеры Кі-67 в костном мозге и аппендиксе после аутопересадки. С помощью корреляционного анализа были изучены внутриорганные и межорганные связи нейромедиаторов: катехоламины/серотонин, катехоламины/гистамин, серотонин/ гистамин в гранулярных люминесцирующих и тучных клетках костного мозга и аппендикса. Подсчитаны абсолютные цифры коэффициента корреляции: при значении коэффициента 0,70- 0,99 - связь в паре сильная. Отрицательные корреляционные связи указывают на то, что в межклеточное пространство выделяется один медиатор или в результате конкурентного вытеснения, или выделения этого медиаторы в разные фазы клеточного цикла. Положительные корреляционные связи указывают на одновременный синтез двух и более нейроаминов в одну из фаз клеточного цикла. При значении серотонинового индекса больше единицы, то преобладает в клетке серотонин. Если показатель был меньше единицы, то превалируют катехоламины.

Результаты и обсуждение.

При аутопересадке в костном мозге мышей экспрессия ядерного антигена Ki 67 отмечается в тучных клетках, выявлено до 3 клеток на одно поле зрения (при малом увеличении, х 100). Гранулярных клеток до 4-5 клеток. Эндотелий слабо экспрессирует данный белок, определяются макрофаги и промиелоциты. Определяется два вида сегментоядерных нейтрофилов: с окрашенным на +4 ядром и неокрашенной цитоплазмой и клеткой, когда цитоплазма определяется на +5 и белое ядро. Цитоплазма мегакариоцитов слабо окрашивается на +3 . Число лимфоцитов достигает до 16 клеток на одно поле зрения.

Отметим, что иммуногистохимическая реакция по сравнению с интактными животными несколько слабее по сравнению с интактными мышами, что указывает на слабую пролиферативную активность клеток в костном мозге.

При аутопересадке костного мозга в аппендиксе среди эпителия выявляются положительными на белок Кі 67 энтерохромаффинные клетки. Экспрессия на белок Кі 67 выявляется в тучных и гранулярных клетках. Увеличение тучных клеток происходит в результате увеличения числа гранулярных клеток до 16 на 
поле зрения, число тучных клеток достигает 15. Преимущественно преобладают гранулярные клетки. Кроме того, резко увеличивается число Кі-67 позитивных клеток в собственной пластинке t. mucose между крипт. Клетки формируют конгломераты, между которыми имеются распадающиеся клетки. Выявляется неравномерность распределения белка в стенках сосудов и в цитоплазме некоторых лейкоцитов. У основания крипт определяются горизонтально расположенные клетки, похожие на миоэпителиальные. В одних из них определяются мелкие равномерно расположенные гранулы, в других - гранулы разного размера. Можно предположить, что это тучные и гранулярные клетки.

Анализ корреляционных связей в костном мозге через 40 мин после аутопересадки в гранулярных клетках выявляет тесную положительную сопряженность между катехоламинами/ катехоламинами. В тучных клетках также все связи стали положительными и сильными. Все это говорит о том, что происходит нейромедиаторное взаимодействие и воздействие нейроаминов в тандеме. Серотониновый индекс чуть выше 1. Это указывает на равные взаимовлияния катехоламинов и серотонина на структуры костного мозга.

При анализе корреляционных связей в структурах аппендикса через 40 мин после аутотрансплантации костного мозга вывялено, что в гранулярных люминесцирующих клетках лимфоидных узелков t.s/mucose связи между катехоламинами и серотонином становятся положительными. Корреляционная связь между катехоламинами и гистамином становится сильной отрицательной, что указывает о действии этих двух нейромедиаторов на клеточные формы лимфоидных узелков независимо друг от друга. В тучных клетках усилилось воздействие на клетки катехоламинов и серотонина. Связь стала сильной. При исследовании межорганных связей через 40 мин при аутотрансплантации костного мозга в гранулярных люминесцирующих клетках между костным мозгом и аппендиксом выявлено наличие сильных корреляционных связей в паре катехоламины / катехоламины. В гранулярных люминесцирующих клетках t. mucose аппендикса выявлена положительная связь по катехоламинам /гистамину, а также между гранулярными люминесцирующими клетками костного мозга и гранулярными клетками лимфоидных узелков по катехоламинам /катехоламинам. Таким образом, в этих двух лимфоидных органах синтез нейроаминов и их выделение происходят одновременно, т.e. они функционируют сопряженно.

Можно заметить по данным корреляционного анализа, что через 40 минут на аутотрансплантацию костного мозга реагируют оба органа, с активацией нейроаминов. Анализируя полученные данные, можно отметить, что при аутопересадке костного мозга изменяется соотношение митотически делящихся клеток в костном мозге и аппендиксе. При данной иммуногистохимической реакции на белок Кі 67 можно выявить активирование диффузно эндокринной системы в виде увеличения количества тучных и гранулярных клеток, расположенных собственной пластинке t. mucose аппендикса, отвечающих за автономную регуляцию органов. Кроме того, также можно отметить, что при аутогенной пересадке в аппендиксе увеличивается активность митотического деления в клетках эпителия, увеличивается число энтерохромаффинных клеток, а также 
происходит резкое увеличение числа тучных и гранулярных клеток, возможно, мигрированные в аппендикс из костного мозга. Нами выявлено, что наибольшее число митотически делящихся клеток определяется в аппендиксе, в костном мозге встречается несколько меньшее число клеток с митозами.

\section{Список используемых источников:}

1. Григорян А.С. Котрансплантация гемопоэтических и мультипотентных мезенхимальных стромальных клеток при онкогематологических заболеваниях увеличивают риск развития рецидивов//Клеточная Трансплантология. 2008. №2 .(3). С.45-50.

2. Мелешенко Т.В. Трансплантация костного мозга. М.: Москва. 2010. 257 с.

3. Abedi M. Haematopoieticstem cell sparticipateinmuscle regeneration // Br. J. Haematol. 2007. Vol. 138(6).

P. 792-801.

(C) 2016, Воробьева О.B.

Анализ иммуногистохимической реакции на белок Кі 67 в костном мозге и аппендиксе при аутогенной костного мозга
(C) 2016, Vorobyova O.V.

Analysis immunohistochemical reactions Ki 67 protein in the bone marrow during the appendix and autologous bone marrow transplantation 